\title{
Comparison of Mentors' and Mentees' Perceptions of Mentees' Research Skill Gains at The Citadel
}

\section{Dr. Simon Thomas Ghanat P.E., The Citadel}

Dr. Simon Ghanat is an Assistant Professor of Civil and Environmental Engineering at The Citadel (Charleston, S.C.). He received his Ph.D., M.S., and B.S. degrees in Civil and Environmental Engineering from Arizona State University. His research interests are in Engineering Education and Geotechnical Earthquake Engineering. He previously taught at Bucknell University and Arizona State University.

\section{Dr. Mary Katherine Zanin, The Citadel}

Dr. Kathy Zanin is an Associate Professor of Immunology, Cell, and Developmental Biology. Her current research interest is exploring histone proteins in the mitochondria. She has also developed a hypothesis for a cure for HIV infection. Dr. Zanin is active in promoting stronger pre-college education in the STEM fields and is a regular participant in activities sponsored by the Center for Excellence and Innovation in Teaching. She was the 2009 recipient of The Citadel's Clinton A. Medbery Award for Dedication in Teaching, the 2018 recipient of the School of Science and Math's Early Career Faculty Award, and the 2018 recipient of the Citadel Faculty Excellence in Service Award. She is also the Pre-Health Advisor, the administrator of the Pre-Health Mentorship Program, and she serves on the Online Education Advisory Board.

\section{Dr. Dena Garner, The Citadel}

Dr. Dena Garner is a full professor in the Department of Health and Human Performance and is the Director of Undergraduate Research and Assistant Provost for Research and Policy at The Citadel in Charleston, South Carolina. She started working at The Citadel in 2004 while completing her postdoctoral fellowship in the Department of Neurology at the Medical University of South Carolina, also located in Charleston. Before her move to Charleston, she worked at Oregon State University in Corvallis, Oregon where she also received her doctoral degree in exercise physiology. She received her Master's degree from the University of South Carolina in exercise physiology and an undergraduate degree from Furman University in Greenville, South Carolina.

\section{Dr. Deirdre D Ragan, The Citadel}

Dr. Deirdre Ragan is a Visiting Assistant Professor in the Department of Mechanical Engineering. Additionally, she is Director of The Citadel Honors Program. She holds a B.S. (Rice University), M.S. and Ph.D. (University of California Santa Barbara) in Materials. Deirdre previously conducted research at a national lab, new product development research in industry, and academic research in Sweden through a Fulbright Fellowship. She holds five patents for ideas conceived and implemented while working in industry. Her interests include mentoring students, high impact teaching methods, and materials research. She teaches upper-level undergraduate and graduate Materials courses in the Mechanical Engineering department as well as undergraduate multidisciplinary courses for the Honors Program.

\section{Dr. Jeffery M. Plumblee II, The Citadel}

Dr. Jeffery Plumblee is an Assistant Professor in the Department of Engineering Leadership and Program Management (ELPM) in the School of Engineering (SOE) at The Citadel. Dr. Plumblee earned his BS in Civil Engineering at Clemson University (2008), Masters in Civil Engineering at Clemson University (2009), Masters of Business Administration at Clemson University (2013), and Doctorate of Philosophy in Civil Engineering at Clemson University (2013). Dr. Plumblee's dissertation research sought to better understand the relationship between sustainability and resilience in residential construction. He continued his work in resilience by helping to kick start a new business line at Fluor Corporation in Business Continuity and Disaster Management Solutions, where he primarily worked as a consultant with Fortune 100 aerospace and pharmaceutical clients. 
Plumblee's research interests focus on building a more resilient society, as well as innovation in resource constrained settings (primarily humanitarian technology and delivery). Plumblee founded an international award winning organization (Clemson Engineers for Developing Countries), which has successfully completed over \$2 million of infrastructure improvements in rural Haiti. He continues his research to drive innovation of experiential learning within engineering education.

\section{Dr. Daniel B. Bornstein, The Citadel}

Dr. Daniel B. Bornstein is an Assistant Professor in the Department of Health and Human Performance at The Citadel, the Military College of South Carolina. Dr. Bornstein began working at The Citadel in 2013 after completing his Ph.D. in Exercise Science from the University of South Carolina. Prior to earning his Ph.D., Dr. Bornstein founded and was C.E.O. of two fitness companies based in Tucson, AZ, the ProActive Performance Institute and Inner Strength Fitness Consultants. After selling those companies in 2007, which focused on individual-level health and performance, Dr. Bornstein's Ph.D. and current research agenda are focused on effective strategies for increasing population-levels of physical activity in order to improve public health and military readiness. Dr. Bornstein has published extensively and presents regularly at national and international conferences in the areas of physical activity and public health including: physical activity monitoring, physical activity communication, physical activity policy, and physical activity messaging. Currently, Dr. Bornstein is leading a series of research studies investigating the impacts of physical inactivity and low physical fitness on military readiness and national security. Dr. Bornstein's research has been featured in over 130 media outlets worldwide, including USA Today, Newsweek, Stars and Stripes, and National Public Radio. Based on his research, Dr. Bornstein has provided numerous briefings to senior military personnel and lawmakers, including briefings at The Pentagon and Capitol Hill. In addition to his research, Dr. Bornstein has held national leadership positions in the physical activity and public health field including: Project Coordinator for the U.S. National Physical Activity Plan from 2009-2014, and Chair of the American Public Health Association's Physical Activity Section from 2015-2016. Dr. Bornstein currently serves on several national committees including the U.S. Department of Health and Human Services' Committee on Physical Activity Communications, the American Heart Association's Expert Advisory Group on Physical Education and Physical Activity Policy in Schools, and he's currently Chair of the National Physical Activity Plan's Communications Committee. Locally, Dr. Bornstein is a member of the Mayor's Health and Wellness Committee for the City of Charleston, and he is Chair of The Citadel's Fitness Pillar.

\section{Mr. John H. Lewis Jr, The Citadel}

John Lewis has worked at the OECD, as a quantitative portfolio manager in London, Boston and New York, in venture capital for early stage companies in Paris and as a professor of finance at universities in Paris, London and Charleston over the past 37 years. His current research interests are in quantitative finance, venture capital, machine learning and high-performance computing. He is currently a Visiting Assistant Professor in Finance at the Citadel and completing his PhD in Finance at Dauphine University in Paris. 


\section{Comparison of Mentors' and Mentees' Perceptions of Mentees' Research Skill Gains at The Citadel}

\section{Introduction}

According to the Council on Undergraduate Research, undergraduate research is defined as "an inquiry or investigation conducted by an undergraduate student that makes an original intellectual or creative contribution to the discipline [1]." As stated in literature, undergraduates who conduct research show improvements in thinking independently, thinking critically, putting ideas together, solving problems, analyzing data, analyzing literature, interpreting research findings, conducting ethical research, writing and communicating [2-9]. Literature also asserts that it is rare for students to have enough opportunity to gain higher-order thinking skills from their undergraduate research experiences [10].

Students involved in undergraduate research also report outcomes that may translate to postgraduation success. For example, students involved in research report greater confidence in their ability to relate to people of different races, cultures, or backgrounds, work successfully on a team, and listen effectively [2]. These skills, individually and/or collectively, could translate into benefits in post-secondary education or professional settings.

In addition to the above benefits to students, faculty who mentor undergraduate student research may benefit by having additional assistance in a laboratory or with data collection, expansion of their own creativity and critical thinking, and overall professional growth [5].

The objective of this study is to examine, from the perspectives of both mentors and mentees, the perception of mentees' gains in research skills. This paper discusses the SURE Program, scope of the student projects, analyses of the mentors' and mentees' perceptions of mentees' research skills, and the potential future improvements for the program.

\section{Institutional Context}

The Citadel's Summer Undergraduate Research Experience (SURE) Program had its inaugural year in the summer of 2017 and was initiated out of the Office of the Provost [11]. The program allows students from all disciplines across campus to participate in either a 5-6 week or an 8-10 week research experience based on the preference of the student and faculty pair [11]. Based on this selection, students are provided a stipend ranging from $\$ 2,500-\$ 4,000$ and on-campus housing and meals, if needed. The faculty mentor working with the student(s) receives a stipend ranging from $\$ 1,000-\$ 1,500$.

The SURE Program strives to improve student skills integral to performing research. Students and their research mentors are expected to work together for eight hours per week for one-onone instruction and research skill development. In addition to conducting research with faculty mentors, mentees are required to attend four lunch meetings throughout the summer experience. These meetings focus on professional development, mentoring, and providing an opportunity for students to discuss research progress with peers. In the first meeting, staff from the campus 
Multimedia Services Office conduct a poster preparation workshop in which they teach the basics of designing a research poster. In the second meeting, staff from the Career Center teach effective resume-building and interview strategies. The final meetings of the program focus on mentoring in the context of faculty and staff. Perhaps the most beneficial meeting to the mentees allows time for collaboration between mentors from various disciplines.

The 2018 SURE participants included ten students from various disciplines across campus. The participants were from the Civil Engineering Department, Mechanical Engineering Department, Chemistry Department, Biology Department, Psychology Department, School of Business, and Health Exercise Sport Science Department. A summary of the participants' characteristics is as follows: gender (two females and eight males) and class standing (two sophomores, six juniors, and two seniors).

One current measure of success of the 2018 SURE Program is the number of student research presentations at the local or regional level. At the local level, each participant presented his or her research in the form of a poster at the beginning of the fall 2018 semester at The Citadel SURE Research Conference. At the regional level, five of the SURE posters were presented at the Southern Conference Research Forum at Wofford University in November 2018 and one student presented his research at the 2019 ASEE-SE Conference in March 2019 at NC State University.

\section{Brief Description of Several 2018 SURE Research Projects}

One research project focused on preliminary research in developing a low-cost passive water generation system, related to the professor's research focus on humanitarian engineering and development. The system under investigation combined desiccant and solar still technologies to harvest humidity from the air at night and evaporate the water in the desiccant, condense it, and collect the water during the day. The student began by exploring the state of the art in solar still technologies and performed a multi-criteria decision analysis to determine an optimal design for prototyping. In parallel, the student and mentor researched appropriate desiccant materials for the specific application. The student constructed two prototypes under supervision of his mentor during the research experience. These prototypes were initially tested solely for their ability to evaporate and collect water in the system using pans of potable water as the source. In addition, desiccants were tested for their ability to absorb and release moisture from humid air. The summer research experience ended prior to full-blown testing, but the mentor plans to continue the project with other undergraduates in the future.

Another project focused on ball bearing degradation as a function of bearing material and loading conditions. The original hypothesis was that ceramic bearings would exhibit less deterioration in extreme loading than standard stainless steel bearings. From the outset, the mentee understood that part of the project would require construction of a testing rig, as there was not an established lab-scale testing methodology for assessing these factors. The construction of a bearing testing rig and the development of a standard research procedure required significantly more time than the mentee had anticipated. The mentee was frustrated at times that it was not possible to quickly gather data on the different bearings and reluctantly 
learned that controlling sources of variation can be extremely difficult. The research concluded with the mentee creating a reproducible testing methodology for assessing bearing performance. While the testing rig and the bearing data was an accomplishment, the mentee was most pleased with his new abilities to troubleshoot and construct equipment, two skills that are of value to the mentee as an engineer. Months after the research was completed, the mentee was selected for an internship at an engineering company. The mentee said his ability to talk about the materials, procedure, and the frustrations of uncontrolled system variation were significant factors in his being offered the internship position.

One mentee studied Histone $\mathrm{H} 3$ in mitochondria. The student chose to observe the effect of oxidative stress (induced by hydrogen peroxide) on the level of mitochondrial $\mathrm{H} 3$, and the effect of a Vitamin E analogue, Trolox, on that stress response. Oxidative stress was quantified by measuring the ratio of reduced to oxidized glutathione, and $\mathrm{H} 3$ intensity was observed by immunocytochemistry and confocal microscopy. The student formulated the hypothesis that Trolox would relieve oxidative stress and consequently would reduce the intensity of $\mathrm{H} 3$ staining in mitochondria. The student designed a controlled experiment to test this hypothesis using the human cancer cell line, Jurkat.

Another SURE project was a feasibility study for objectively assessing sleep quality and quantity in a college student population. Ultimately, the purpose of this line of research was to investigate associations between objectively measured sleep and physical fitness, mental health, and academic performance among college students. Due to the expense associated with objective sleep monitoring, it was important to determine the most cost-efficient means for validly and reliably assessing sleep behavior. Therefore, the essential purpose of this study was to assess the feasibility of using a longitudinal design as compared to a repeated, cross-sectional design, as a repeated cross-sectional design would be substantially less expensive to conduct. The student was involved in all aspects of the study including literature review, planning for data collection, actual data collection, data analysis, and presentation of the findings. Findings from the study were that data quality were significantly better in the longitudinal group as compared to the repeated cross-sectional group, showing that if a larger scale study were to be conducted it would require significant resources to be efficacious.

It is important to note that due to small sample size, no comparisons were made among disciplines.

\section{Study Methods}

It has been shown in literature that mentees perceive themselves to have gained research skills because of conducting undergraduate research [7], but there is still a question if mentors also perceive these gains. Mentors have tended to strongly agree that mentees gain the ability to collect data $[2,8]$, relate well to people of different backgrounds $[2,8]$, and work in teams $[2,8$, 12]. Mentors have also rated mentees relatively high on skills such as understanding and synthesizing the research in the discipline, formulating a hypothesis, designing a study, analyzing data, orally presenting results, thinking creatively, and working independently $[2,8$, 12]. Mentors have indicated that their mentees gained the following skills from undergraduate 
research: learning a topic in depth; applying knowledge to a real situation; proficiency in lab techniques; and learning to work and think independently [3,8]. Typically, mentors rate mentees' ability to write papers for publication as lower than other research skills $[2,7,8]$. This is because mentees rarely get the opportunity to publish papers based on their research [7, 8]. The following describes the guiding research question for this study:

Do mentors and mentees have same perception about the mentees' improvement in research skills after participating in the SURE Program at The Citadel?

\section{Assessment Measure}

The stated research question was examined indirectly by analyzing a survey of mentee and mentor perception. A fifteen-question survey was developed based upon the commonly stated research skills obtained as results of undergraduate research in literature [8]. The survey was only administered at the end of the program. A total of 10 mentees and 10 mentors completed the survey. The mentors' and mentees' perceptions of mentees' research skills were measured by analyzing a 1-5 Likert Scale survey (' 1 ' indicating that the skill is not at all improved and ' 5 ' indicating that that the skill is very much improved). Mentees and mentors were asked to assess improvements in the following skills after participating in the SURE Program:

1. Research design

2. Formulating a hypothesis

3. Data entry

4. Analyzing data

5. Interpreting data

6. Critical thinking

7. Thinking creatively

8. Understanding the ethics of research

9. Locating past research on a topic

10. Evaluating past research on a topic

11. Summarizing and hypothesizing past research on a topic

12. Oral communication

13. Writing skills

14. Using technology

15. Working independently

\section{Results and Discussion}

The mean and standard deviation of each survey response was determined and the results are shown with standard errors in Figure 1. Mentees gave their lowest perception rating (mean 3.4) to gains in oral communication skills, writing skills, and the ethics of research, while mentors ranked mentee gains in working independently the lowest (mean 2.9). For the mentors, the greatest mentee gains were perceived in using technology (mean 4.0) and critical thinking (mean 3.8), while mentees ranked their own gains in analyzing data the highest (mean 4.6). 


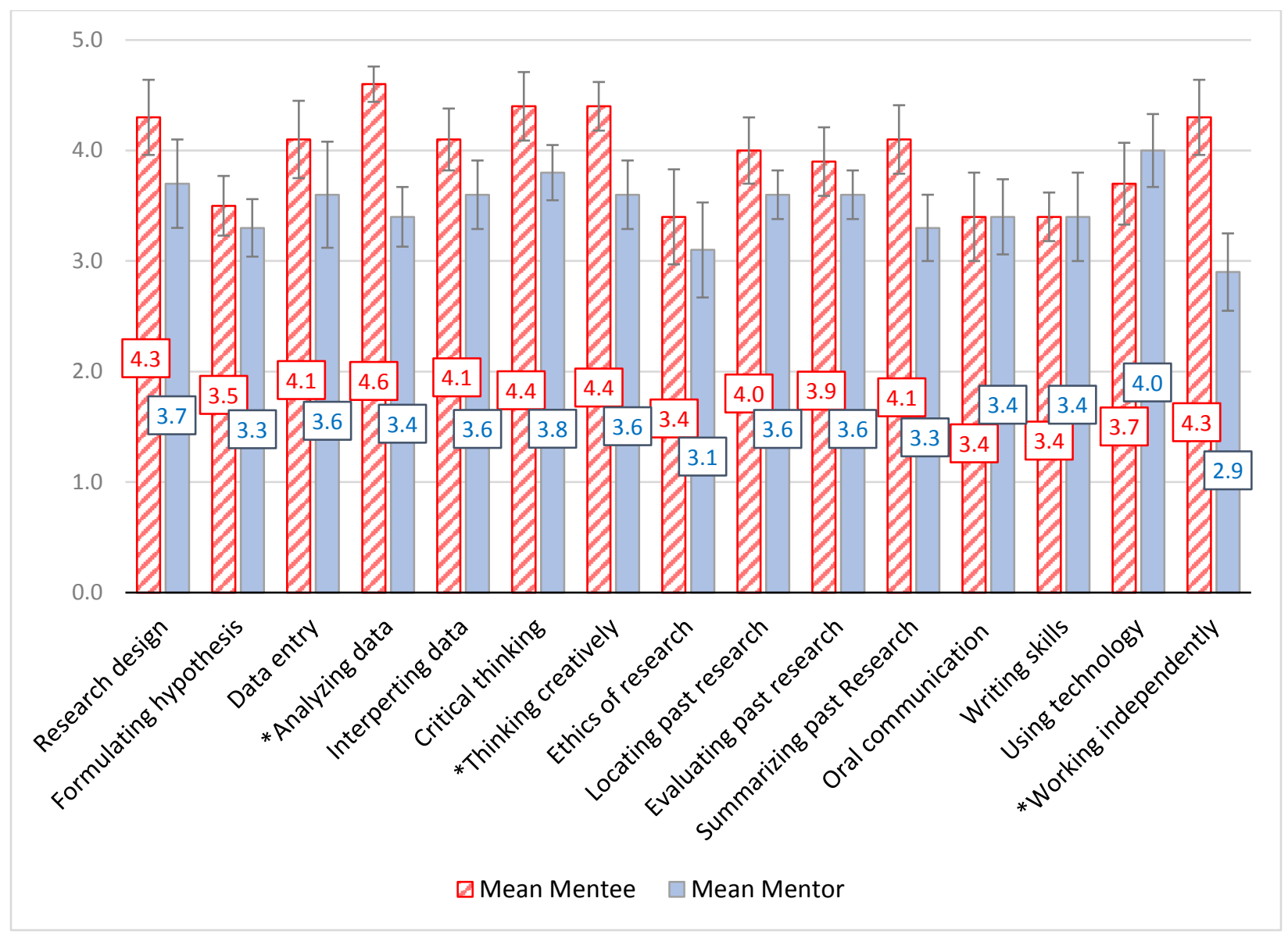

Figure 1. Mean and standard deviation of mentors' and mentees' perception + /- Standard Error, * $\mathrm{P}<0.05, \mathrm{~N}_{1}=10$ and $\mathrm{N}_{2}=10$ (' 1 ' indicating that the skill is not at all improved and ' 5 ' indicating that that the skill is very much improved.)

Comparison of the mentor and mentee mean perception scores was completed using the 2sample t-test at five percent level of significance, and the results are shown in Table 1. It was hypothesized that the mean of perception scores of mentor and mentee are not different from each other (i.e., $\mathrm{H}_{0}: \mu_{1}=\mu_{2}, \mathrm{H}_{\mathrm{a}}: \mu_{1} \neq \mu_{2}$ ). The statistical test, conducted for each question to test for statistically significant differences between mentor and mentee responses, showed students perceived significant differences in their own gains in analyzing data, thinking creatively, and working independently. This is not particularly surprising: research has found self-ratings of traits, abilities, performance, or leadership typically be higher than the ratings provided by observers $[13,14]$. Interestingly, literature also assert that such a self-enhancement bias may be psychologically healthy in that it reflects positive self-evaluation and results in both fewer negative thoughts and also higher expectancies for success in new endeavors $[13,14]$. 
Table 1. Summary results of descriptive statistics and 2-sample t-test statistical analysis. Research skills marked with * indicate those with significant differences between mentor and mentee mean perception of gain scores.

\begin{tabular}{|c|c|c|c|c|c|c|c|c|}
\hline \multirow{2}{*}{ Research Skills } & \multicolumn{3}{|c|}{$\begin{array}{l}\text { Mentors' Perceptions } \\
\qquad \mathrm{N}=10 \\
\end{array}$} & \multicolumn{3}{|c|}{$\begin{array}{l}\text { Mentees' Perceptions } \\
\mathrm{N}=10 \\
\end{array}$} & \multirow{2}{*}{ t-stat } & \multirow{2}{*}{$\begin{array}{c}\mathrm{P} \\
\text { value }\end{array}$} \\
\hline & Mean & $\begin{array}{c}\text { Standard } \\
\text { Deviation }\end{array}$ & $\begin{array}{c}\text { Standard } \\
\text { Error }\end{array}$ & Mean & $\begin{array}{c}\text { Standard } \\
\text { Deviation }\end{array}$ & $\begin{array}{c}\text { Standard } \\
\text { Error }\end{array}$ & & \\
\hline $\begin{array}{l}\text { Research } \\
\text { design }\end{array}$ & 3.7 & 1.25 & 0.40 & 4.3 & 1.06 & 0.34 & -1.157 & 0.2624 \\
\hline $\begin{array}{l}\text { Formulating } \\
\text { hypothesis }\end{array}$ & 3.3 & 0.83 & 0.26 & 3.5 & 0.85 & 0.27 & -0.535 & 0.5595 \\
\hline Data entry & 3.6 & 1.51 & 0.48 & 4.1 & 1.1 & 0.35 & -0.848 & 0.4077 \\
\hline $\begin{array}{l}\text { *Analyzing } \\
\text { data }\end{array}$ & 3.4 & 0.84 & 0.27 & 4.6 & 0.52 & 0.16 & -3.841 & $<0.05$ \\
\hline $\begin{array}{l}\text { Interpreting } \\
\text { data }\end{array}$ & 3.6 & 0.97 & 0.31 & 4.1 & 0.88 & 0.28 & -1.213 & 0.2409 \\
\hline $\begin{array}{l}\text { Critical } \\
\text { thinking }\end{array}$ & 3.8 & 0.79 & 0.25 & 4.4 & 0.97 & 0.31 & -1.521 & 0.1466 \\
\hline $\begin{array}{l}* \text { Thinking } \\
\text { creatively }\end{array}$ & 3.6 & 0.97 & 0.31 & 4.4 & 0.7 & 0.22 & -2.121 & $<0.05$ \\
\hline $\begin{array}{l}\text { Ethics of } \\
\text { research }\end{array}$ & 3.1 & 1.37 & 0.43 & 3.4 & 1.35 & 0.43 & -0.493 & 0.6278 \\
\hline $\begin{array}{l}\text { Locating past } \\
\text { research }\end{array}$ & 3.6 & 0.7 & 0.22 & 4 & 0.94 & 0.30 & -1.078 & 0.2963 \\
\hline $\begin{array}{l}\text { Evaluating past } \\
\text { research }\end{array}$ & 3.6 & 0.7 & 0.22 & 3.9 & 0.99 & 0.31 & -0.781 & 0.4465 \\
\hline $\begin{array}{l}\text { Summarizing } \\
\text { past research }\end{array}$ & 3.3 & 0.95 & 0.30 & 4.1 & 0.99 & 0.31 & -1.841 & 0.0822 \\
\hline $\begin{array}{c}\text { Oral } \\
\text { communication }\end{array}$ & 3.4 & 1.07 & 0.34 & 3.4 & 1.26 & 0.40 & 0.000 & 1.000 \\
\hline Writing skills & 3.4 & 1.26 & 0.40 & 3.4 & 0.7 & 0.22 & 0.000 & 1.000 \\
\hline $\begin{array}{c}\text { Using } \\
\text { technology }\end{array}$ & 4 & 1.05 & 0.33 & 3.7 & 1.16 & 0.37 & 0.605 & 0.5525 \\
\hline $\begin{array}{c}\text { *Working } \\
\text { independently }\end{array}$ & 2.9 & 1.1 & 0.35 & 4.3 & 1.06 & 0.34 & -2.898 & $<0.05$ \\
\hline
\end{tabular}

\section{Conclusions and Potential Future Improvements for the Program}

\section{Conclusions:}


This study examined the perception of gains in research skills obtained by the mentees in the SURE Program from the perspective of both mentors and mentees. The comparison of mentors' and mentees' ratings revealed that:

- Mentors and mentees rated gains in oral and written communication and formulating hypothesis skills most similarly.

- Mentees rated their skill development higher than their mentors did (with the exception of using technology), only the mentees' assessment of their own gains in data analysis, creative thought, and independent work were significantly higher than their mentors' perceptions.

\section{Future Improvements for the Program:}

To better assess the success of the SURE Program in helping mentees gain research skills, we could follow our students' improvement in their undergraduate science coursework performance and their success rate in any application to graduate school by comparison with similar students who did not participate in the SURE Program.

While the mentors participating in the SURE Program already possessed researching mentoring skills and a rapport with students, it is conceivable that the mentees' research experience and assessment could be augmented with additional mentor training. Previous research [15] has shown that mentor training can improve a mentor's ability to assess the skills of their mentees and result in a closer match in mentor and mentee perceived abilities.

The significant gaps between mentee and mentor perceptions of 1) gains in understanding research ethics, 2) hypothesis formation, and 3) data analysis might be closed by adding a student workshop at the beginning of the summer to teach the mentees about those and other research skills. This workshop might include case studies and other interactive learning activities.

It also would be of interest to have mentees from previous SURE Programs return to act as a part-time mentor to new mentees. Not only would the previous mentees be able to connect to the new mentees in a unique way, the previous mentees would have the opportunity to put their developed skills into practice. Upon serving in a mentor role, the previous mentees may assess their skills differently.

\section{References}

[1] Council on Undergraduate Research, About the Council on Undergraduate Research, 2009. Retrieved from http://www.cur.org/about.html

[2] M.F. Cox, A. Andriot, Mentor and undergraduate student comparisons of students' research skills. Journal of STEM Education, 10, 31-39, 2009.

[3] D. Lopatto, The essential features of undergraduate research. Council on Undergraduate Research Quarterly, 24, 139-142, 2003. 
[4] K.W. Bauer, J.S. Bennett, Alumni perceptions used to assess undergraduate research experience. Journal of Higher Education, 74, 210-230, 2003.

[5] S.F. Chopin, Undergraduate research experiences: The translation of science education from reading to doing. The Anatomical Record, 269, 2-10, 2002.

[6] S. Hu, K. Scheuch, R. Schwartz, J.G. Gayles, S. Li, "Reinventing Undergraduate Research: Engaging College Students in Research and Creative Activities", San Francisco, CA: Wiley/Jossey-Bass, 2008.

[7] A. Hunter, S.L. Laursen, E. Seymour, Becoming a scientist: The role of undergraduate research in students' cognitive, personal, and professional development. Science Education, 91, 36-74, 2006.

[8] Perspective on Undergraduate Research and Mentoring, PURM 1.1, Oct 2011.

[9] J. Ishiyama, Does early participation in undergraduate research benefit social science and humanities students? College Student Journal, 36, 380-387, 2002.

[10] H. Thiry, S. Laursen, Evaluation of the undergraduate research programs of the Biological Science Initiative: Students' intellectual, personal and professional outcomes from participation in research. Report prepared for the Howard Hughes Medical Institute. Boulder, CO: Ethnography and Evaluation Research, 2009.

[11] S.T., Ghanat, D. Garner, J. Howison, S. Banik, B. Swart, M. Verdicchio, R. Hunter (2018), Students' Perception of Summer Undergraduate Research Experience: Across the Disciplines, proceeding of 2018 American Society of Engineering Education National Conference, Salt Lake City, UT, 2018

[12] A.L. Zydney, J.S. Bennett, A. Shahid, K.W. Bauer, Faculty perspectives regarding the undergraduate research experience in science and engineering. Journal of Engineering Education, 91, 291-297, 2002.

[13] C.M. Kardash, Evaluation of an undergraduate research experience: Perceptions of undergraduate interns and their faculty mentors. Journal of Educational Psychology, 92, 191-201, 2000.

[14] L.E. Atwater, F.J. Yammarino, Self-other rating agreement: A review and model. Research in Personnel and Human Resources Management, 15, 121-174, 1997.

[15] C. Pfund, C. Pribbenow, J. Branchaw, S. Miller Lauffer, J. Handelsman, Professional skills - The merits of training mentors. Science, 311. 473-4, 2006. 